\title{
Benign pineal cyst lined with normal choroid plexus mimicking tumour in a young girl with exotropia
}

\author{
Yuanfan Yang, ${ }^{1}$ Michael L Levy, ${ }^{2}$ John Ross Crawford ${ }^{3}$
}

${ }^{1}$ Peking Union Medical College Hospital, Dongcheng-Qū, Beijing, China

${ }^{2}$ Department of Neurosurgery, University of California San Diego, San Diego, California, USA

${ }^{3}$ Department of Neurosciences and Pediatrics, University of California San Diego, San Diego, California, USA

\section{Correspondence to} Dr John Ross Crawford, jrcrawford@ucsd.edu

Accepted 9 January 2016
CrossMark

To cite: Yang Y, Levy ML, Crawford JR. BMJ Case Rep Published online: [please include Day Month Year] doi:10.1136/bcr-2015214170

\section{DESCRIPTION}

A 4-year-old girl presented with a 4-month history of progressive exotropia. There was no headache, no impaired upgaze, no nystagmus and no vision changes. Complete neurological examination was otherwise normal. MRI of the brain revealed a $1.5 \mathrm{~cm}$ cystic lesion in the pineal region. The cyst had a smooth margin lined by a thin wall of $<1 \mathrm{~mm}$ that was homogenously enhancing on contrast scan. Compared to cerebrospinal fluid, the cyst content was isointense in T1 and hyperintense on T2-weighted images (figure 1). The pineal gland was slightly displaced anteriorly and laterally to the left without hydrocephalus. Given the unusual appearance with an associated new neurological deficit, an endoscopic biopsy and resection of the cyst was performed. Pathology demonstrated benign choroid plexus and neuroglial tissue without evidence of tumour (figure 2).

Pineal cysts are common incidental findings on brain MRI of children. Normally, the pineal cyst wall consists of an inner layer of glial tissue rich in Rosenthal fibres, residue pineal parenchyma and an outer fibrous layer. ${ }^{1} 2$ The presence of choroid plexus is very rare. Embryologically, the pineal gland arises from a diverticulum from the roof of the third ventricle. The distal tip of the diverticulum becomes a small cavity in the pineal gland, which may enlarge and become a cyst. One animal histology has shown choroidal-like cells in association with the cerebrospinal fluid (CSF)-contacting

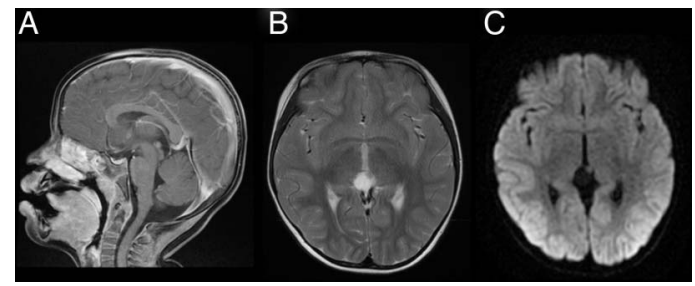

Figure 1 Sagittal T1-weighted image with contrast revealling a cystic lesion in the pineal region, with a thin wall that is homogeneously enhancing $(A)$. On axial T2-weighted image, the cyst content is more hyperdense than cerebrospinal fluid and the pineal gland is displaced to the left (B) without evidence of reduced diffusivity on diffusion-weighted imaging sequences (C).

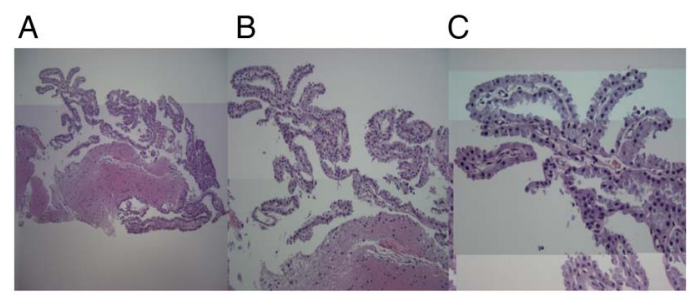

Figure $2 \quad(A-C)$ Permanent histological sections obtained following biopsy revealling neuroglial tissue surrounded by benign choroid plexus projecting to the surface without evidence of neoplasm.

pinealocytes. ${ }^{3}$ Given the role of CSF production in the choroidal plexus, this close association may propose a mechanism of fluid production in the pineal cyst, which may mimic cystic pineal tumours.

\section{Learning points}

Pineal cyst is a common incidental finding in brain MRI of children. Surgery is generally indicated only when the patient is symptomatic or the lesion atypical.

- Pineal cyst walls may comprise of an inner layer of neural glial tissue, residue pineal parenchyma and an outer fibrous layer, which may mimic tumours.

Twitter Follow Yuanfan Yang at @yangyuanfan@msn.com Competing interests None declared.

Patient consent Obtained.

Provenance and peer review Not commissioned; externally pee reviewed.

\section{REFERENCES}

1 Fleege MA, Miller GM, Fletcher GP, et al. Benign glial cysts of the pineal gland: unusual imaging characteristics with histologic correlation. Am J Neuroradiol 1994;15:161-6.

2 Cooper ER. The human pineal gland and pineal cysts. J Anat 1932;67:28-46.

3 Welsh MG. Intraventricular blood vessels associated with the deep pineal gland of the Mongolian gerbil, Meriones unguiculatus. Cell Tissue Res 1987:249:587-92. 
Copyright 2016 BMJ Publishing Group. All rights reserved. For permission to reuse any of this content visit http://group.bmj.com/group/rights-licensing/permissions.

BMJ Case Report Fellows may re-use this article for personal use and teaching without any further permission.

Become a Fellow of BMJ Case Reports today and you can:

- Submit as many cases as you like

- Enjoy fast sympathetic peer review and rapid publication of accepted articles

- Access all the published articles

- Re-use any of the published material for personal use and teaching without further permission

For information on Institutional Fellowships contact consortiasales@bmjgroup.com

Visit casereports.bmj.com for more articles like this and to become a Fellow 